\title{
Evaluation of new agricultural tractors engines by using a portable dynamometer
}

\author{
Avaliação de motores de tratores agrícolas novos utilizando dinamômetro móvel
}

\author{
Marcelo Silveira de Farias $^{I^{*}}$ José Fernando Schlosser $^{I I}$ Javier Solis Estrada \\ Ulisses Giacomini Frantz ${ }^{\text {III }}$ Fabrício Azevedo Rodrigues ${ }^{I}$
}

\section{ABSTRACT}

Official agricultural engineering testing aims to determine torque and power, which are important information for decision making when buying an agricultural tractor. In this research the torque and maximum power values provided by manufacturers with the dynamometer tests values, were compared. Forty new agricultural tractors commercialized in the brazilian market were used. Tractors were classified according to the power range in: Class I (less than or equal $22.1 \mathrm{~kW})$; Class II (between 22.1 and $51.5 \mathrm{~kW})$; Class III (51.5 and $73.5 \mathrm{~kW})$; Class IV (73.5 and $117.7 \mathrm{~kW})$; and Class V $(117.7$ and $183.9 \mathrm{~kW})$. Variables were analyzed with the statistic $t$-Student test $(P \geq 0.05)$. Class IV tractors engines power is bigger in comparison to the values specified by manufacturers. As for Class III tractors engines, torque values observed were bigger when compared to the specified, while for Class $V$ was presented smaller values. As conclusion, with respect to the maximum engine power, it was verified that $67.5 \%$ of the evaluated tractors meet the information provided by manufactures.

Key words: diesel cycle, torque, power.

\section{RESUMO}

Os ensaios oficiais de motores agrícolas visam à determinação do torque e potência, que são informações importantes para a tomada de decisão no momento da compra de uma máquina agrícola. Neste trabalho, foram comparados os valores de torque e potência máxima do motor, fornecidas pelos fabricantes com os dados obtidos a partir de testes dinamométricos. Para tanto, utilizaramse 40 tratores agrícolas novos comercializados no mercado brasileiro. Os tratores foram classificados quanto à faixa de potência em: Classe I (menor ou igual a 22,1kW); Classe II (entre 22,1 e 51,5kW); Classe III (51,5 e 73,5kW); Classe IV (73,5 e 117,7kW); e Classe V (117,7 e 183,9 $k W)$. As variáveis foram submetidas ao teste estatístico $t$ de Student $(P \geq 0,05)$. A potência dos motores dos tratores da Classe IV é maior em comparação aos especificados pelos fabricantes. Para os motores de tratores da Classe III, os valores observados de torque são maiores em relação aos especificados, enquanto que, para os da Classe $V$, esses valores foram menores. Como conclusão, no que diz respeito à potência máxima do motor, verificou-se que $67,5 \%$ dos tratores avaliados atendem às informações disponibilizadas pelos fabricantes.

Palavras-chave: ciclo diesel, torque, potência.

In Brazil, for more than 20 years there was no official test on agricultural engines. However, educational and research institutions, as well as agricultural machines manufacturers perform some dynamometric tests for engine performance information (NIETIEDT et al., 2011).

In order to conduct performance evaluation, internal combustion engines should be accessed through full load tests, through the flywheel or the Power take-off (PTO). On agricultural tractors, it is usually applied

IPrograma de Pós-graduação em Engenharia Agrícola (PPGEA), Universidade Federal de Santa Maria (UFSM), 97105-900, Santa Maria, RS, Brasil. E-mail: silveira farias@hotmail.com. "Corresponding author.

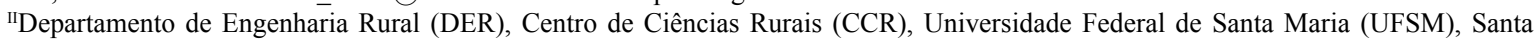
Maria, RS, Brasil.

IIIniversidade Federal do Pampa (UNIPAMPA), Dom Pedrito, RS, Brasil. 
the assessment through PTO (CORRÊA et al., 2008; FIORESE et al., 2012).

One of the main interests of consumers refers to the acquisition of tractors properly adjusted to their reality, to be sure of the technical specifications of such tractors, which will be the basis of good measurement of the mechanized activities on farms (GARAY et al., 2013).

The power achieved in the dynamometric tests of engines can be subject to a tolerance on the power stated by the manufacturer. The existence of tolerance and its scope should be established by the engine manufacturer itself (ABNT, 1995). Thus, the Diesel cycle engine that equips tractors plays an important role in agriculture since it is the component that forms the basis for the decision of purchasing the tractor, mainly through the analysis of power factor (SILVEIRA et al., 2008).

Due to the need to know the actual situation of engines performance in the new agricultural tractors, the following research aimed to compare the torque and maximum engine power values obtained from dynamometer tests with the technical information provided by the manufacturers.

Forty tractors were assessed, being separated according to the trademarks of the tractors and engines, power classes and engine settings. Data were collected through dynamometric tests conducted on the premises of agricultural machinery concessionaires of a region in the state of Rio Grande do Sul called Depressão Central. The tractors were ranked for power range in: Class I (less than or equal to $22.1 \mathrm{~kW}$ ); Class II (between 22.1 and $51.5 \mathrm{~kW})$; Class III (51.5 and $73.5 \mathrm{~kW})$; Class IV $(73.5$ and $117.7 \mathrm{~kW})$, and Class V (117.7 and $183.9 \mathrm{~kW})$. The rating has been adapted from MÁRQUEZ (2012).

For testing, it was used a portable dynamometer bench, brand EGGERS ${ }^{\circledR}$, model PT 301 MES. Through this, torque and maximum engine power values were collected, performing three repetitions for each tractor model evaluated. The test procedures followed the instructions contained in the Code 2 of OECD (2014).

The recorded values were fixed in $10 \%$, considering the losses in transmission between the engine and the PTO, mentioned by rule ASAE (2003). Subsequently, data collected was compared with the results published by the manufacturers.
Data were statistically analyzed in order to verify the significance of the differences between specified and observed values, through the t-Student test, with $5 \%$ level of probability error $(\mathrm{P} \geq 0.05)$. Regarding average power observed in each class, it was calculated the confidence interval (CI), which represents the deviation, for more or less, which, statistically, is estimated to be inserted in the samples of tested engines (MIALHE, 1996).

According to the proposed classification, $50 \%$ of the tractors which had its engines assessed belong to Class III, 30\% to Class IV, and the rest are divided between Class II and Class V (10\% each) (Figure 1A). These values can be attributed to power demanded by the farming operations of Depressão Central region in the state of Rio Grande do Sul.

Concerning the division of tractors by commercial brands (Figure 1B), there was predominance of the brand Massey Ferguson ${ }^{\circledR}$ MF (70.0\%), followed by Valtra ${ }^{\circledR}$ - VT $(15.0 \%)$, John Deere ${ }^{\circledR}-$ JD and New Holland ${ }^{\circledR}-\mathrm{NH}$, both with $7.5 \%$.

At a total, six brands comprised the sample engines (Figure 1C), and the engine brand AGCO Power $^{\circledR}$ was most frequently found $(37.5 \%)$. Among the evaluated types, which showed the highest representation was the four cylinders naturally aspirated (47.5\%), followed by the four cylinders turbo charged $(25.0 \%)$, three and six cylinders turbocharged, three cylinders aspirated, and six cylinders turbocharged intercooler (Figure 1D).

A different percentage is noticed between $-3.8 \%$ and $5.2 \%$ when analyzing the torque values (specified and observed) for tractors Class II, which means that the tractor number 4 has $13.0 \mathrm{Nm}$ more when compared with the value reported by the manufacturer and the number 1 with $6.3 \mathrm{Nm}$ less (Table 1 ). The low value of torque observed in Class V engines, according to MÁRQUEZ (2012), might be explained by the type of fuel injection pump, because for high power engines, it is necessary to use an electronic fuel injection system.

There was a difference between the average torque value specified and observed in Classes III and V, while for power difference it occurred only in Class IV. It was also observed that the accuracy of torque and power values specified by manufacturers did not have a direct relationship with the size of the engine. 


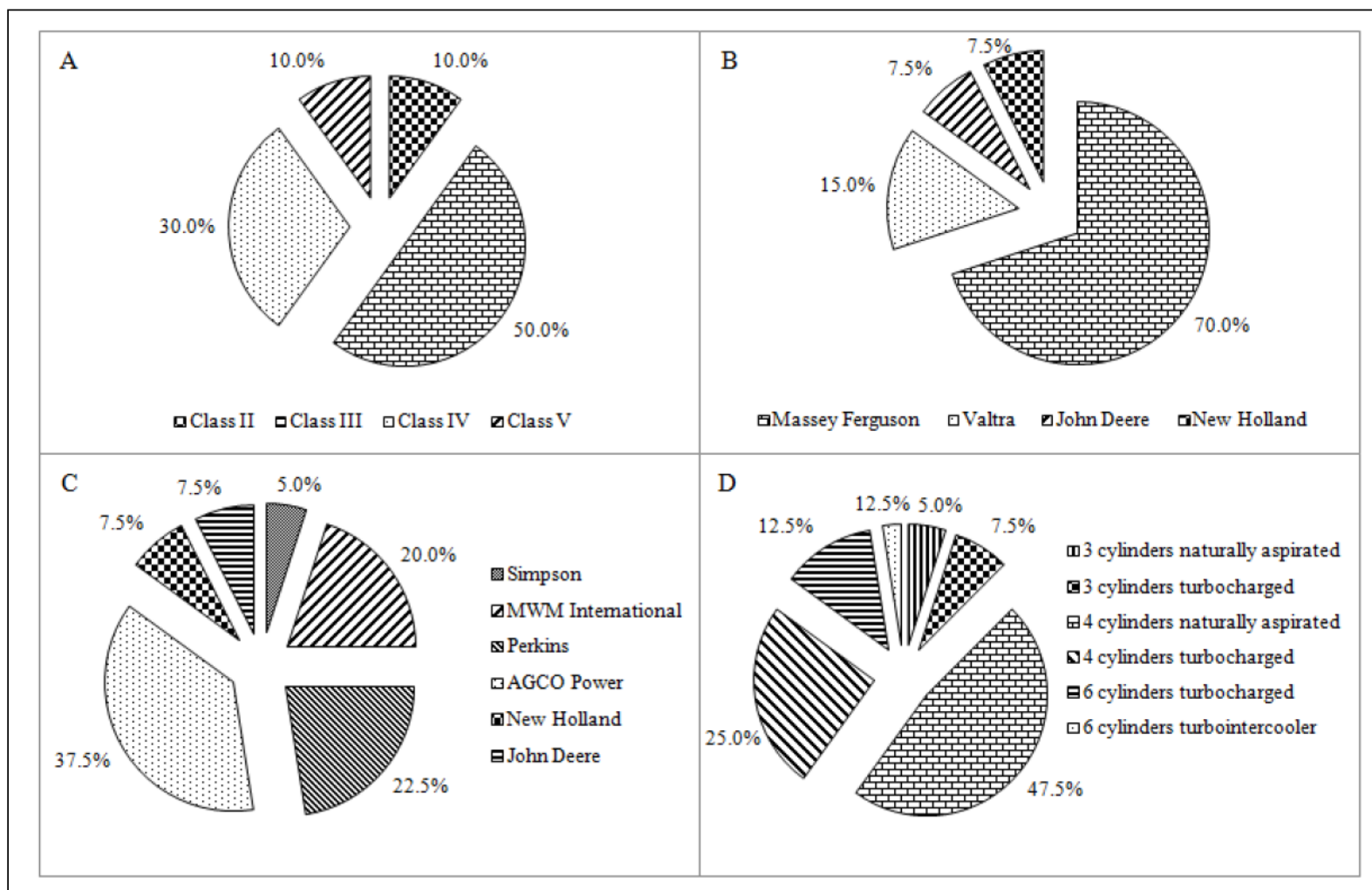

Figure 1 - Distribution of agricultural tractors for classes (A) and trademark (B); and distribution of the engines about the trademark (C) and engine type (D).

The results corroborate those presented by CORREAA et al. (2008), when detecting that the power obtained was $11.5 \%$ lower than the value specified by the manufacturer, in evaluating the performance of a new Diesel engine with $46 \mathrm{~kW}$ power, belonging to Class II.

Confidence intervals and standard deviations around the mean values of the observed powers found were 1.64 (1.39); 0.51 (1.32); 1.95 (3.77), and 6.80 (5.78) for Class II; III; IV, and $\mathrm{V}$, respectively. This means, for example, that the maximum power observed in the engines of tractors Class II can have a tolerance of $1.64 \mathrm{~kW}$, for more or less, on the maximum power specified. Thus, using this methodology, it can be observed that $27.5 \%$ of the tractors are subjected to dynamometer testing according to the manufacturer regarding the maximum engine power (Table 1).
Considering the positive percentage difference between the maximum power observed and specified (Table 1), one can see that $67.5 \%$ of the evaluated tractors meet the information contained in manufacturers catalogs. The lower values of torque and maximum power found in some tractors may adversely affect their field performance by interfering in the machines and implements size. In addition, at the time of acquisition, may cause economic losses to the farmer, as its final value is associated with the engine power.

\section{ACKNOWLEDGEMENTS}

The authors are grateful to the Coordenação de Aperfeiçoamento de Pessoal de Nível Superior (CAPES) for financial support. Also to the Conselho Nacional de Desenvolvimento Científico e Tecnológico (CNPq) for research productivity scholarship of the second author. 
Table 1 - Comparison between torque and maximum engine power, specified by manufacturers and observed through dynamometer tests, by means $t-S t u d e n t$ test $(\mathrm{P} \geq 0.05)$, for the forty agricultural tractors evaluated, according to power Class.

\begin{tabular}{|c|c|c|c|c|c|c|c|c|c|c|}
\hline \multirow{2}{*}{ N. } & \multirow{2}{*}{ Model } & \multirow{2}{*}{ Class } & \multicolumn{4}{|c|}{---------------------Torque ${ }^{* *}(\mathrm{Nm})---------------------$} & \multicolumn{4}{|c|}{ 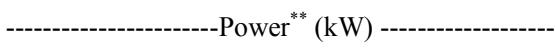 } \\
\hline & & & Spc. & Obs. & Dif. (\%) & Dif. (A) & Spc. & Obs. & Dif. (\%) & Dif. (A) \\
\hline 1 & MF 255A & \multirow{4}{*}{ II } & 167 & 160.7 & -3.8 & 6.3 & 36.8 & 32.4 & -11.9 & 4.4 \\
\hline 2 & MF $255 \mathrm{~A}$ & & 167 & 168.7 & 1.0 & 1.7 & 36.8 & 34.0 & -7.5 & 2.8 \\
\hline 3 & MF $4265^{*}$ & & 235.5 & 246.5 & 4.7 & 11.0 & 47.8 & 47.3 & -1.0 & 0.5 \\
\hline 4 & MF $4265^{*}$ & & 252 & 265.0 & 5.2 & 13.0 & 47.8 & 47.6 & -0.4 & 0.2 \\
\hline 5 & MF $4275^{*}$ & \multirow{20}{*}{ III } & 267 & 315.3 & 18.1 & 48.3 & 55.2 & 55.6 & 0.8 & 0.4 \\
\hline 6 & $\operatorname{MF} 4275^{*}$ & & 267 & 289.6 & 8.4 & 22.6 & 55.2 & 55.9 & 1.3 & 0.7 \\
\hline 7 & $\operatorname{MF} 4275^{*}$ & & 267 & 302.8 & 13.4 & 35.8 & 55.2 & 55.5 & 0.7 & 0.3 \\
\hline 8 & MF $4275^{*}$ & & 267 & 308.1 & 15.4 & 41.1 & 55.2 & 57.6 & 4.4 & 2.4 \\
\hline 9 & $\operatorname{MF} 4275^{*}$ & & 267 & 279.8 & 4.8 & 12.8 & 55.2 & 56.6 & 2.6 & 1.4 \\
\hline 10 & MF 4275 & & 267 & 276.7 & 3.6 & 9.7 & 55.2 & 51.9 & -5.9 & 3.3 \\
\hline 11 & $\operatorname{MF} 4275^{*}$ & & 267 & 278.3 & 1.2 & 11.3 & 55.2 & 55.0 & -0.4 & 0.2 \\
\hline 12 & MF 4275 & & 267 & 300.2 & 9.2 & 33.2 & 55.2 & 53.0 & -3.9 & 2.2 \\
\hline 13 & $\operatorname{MF} 4275^{*}$ & & 267 & 315.3 & 14.7 & 48.3 & 55.2 & 56.4 & 2.2 & 1.2 \\
\hline 14 & $\operatorname{MF} 4275^{*}$ & & 267 & 295.6 & 7.5 & 28.6 & 55.2 & 55.1 & -0.1 & 0.1 \\
\hline 15 & JD 5078E & & 257.4 & 279.8 & 8.7 & 22.4 & 55.3 & 53.3 & -3.6 & 2.0 \\
\hline 16 & JD $5078 \mathrm{E}^{*}$ & & 257.4 & 277.1 & 7.7 & 19.7 & 55.3 & 55.7 & 0.7 & 0.4 \\
\hline 17 & JD 5078E & & 257.4 & 266.2 & 3.4 & 8.8 & 55.3 & 53.3 & -3.6 & 2.0 \\
\hline 18 & NH TL75E & & 264 & 291.9 & 10.6 & 27.9 & 56.6 & 59.0 & 4.2 & 2.4 \\
\hline 19 & NH TL75E* & & 264 & 305.1 & 15.6 & 41.1 & 56.6 & 59.5 & 5.1 & 2.9 \\
\hline 20 & NH TL75E & & 264 & 279.8 & 6.0 & 15.8 & 56.6 & 55.9 & -1.4 & 0.7 \\
\hline 21 & VT A750 & & 296 & 310.8 & 5.0 & 14.8 & 57.4 & 53.3 & -7.2 & 4.1 \\
\hline 22 & VT A750 & & 296 & 310.4 & 4.9 & 14.4 & 57.4 & 56.4 & -1.7 & 1.0 \\
\hline 23 & VT A750* & & 296 & 311.9 & 5.4 & 15.9 & 57.4 & 59.8 & 4.3 & 2.4 \\
\hline 24 & MF 4283 & & 288 & 300.2 & 4.2 & 12.2 & 62.5 & 55.5 & -11.2 & 7.0 \\
\hline 25 & MF $4291^{*}$ & \multirow{12}{*}{ IV } & 400 & 415.1 & 3.8 & 15.1 & 77.2 & 81.5 & 5.6 & 4.3 \\
\hline 26 & MF $4291^{*}$ & & 400 & 372.0 & -7.0 & 28.0 & 77.2 & 78.2 & 1.3 & 1.0 \\
\hline 27 & MF $4291^{*}$ & & 400 & 401.5 & 0.4 & 1.5 & 77.2 & 82.7 & 7.1 & 5.5 \\
\hline 28 & MF 4291* & & 400 & 372.0 & -7.0 & 28.0 & 77.2 & 79.3 & 2.6 & 2.1 \\
\hline 29 & VT BM100 & & 398 & 404.5 & 1.6 & 6.5 & 78.0 & 74.3 & -4.7 & 3.7 \\
\hline 30 & VT BM100* & & 398 & 415.1 & 4.3 & 17.1 & 78.0 & 79.5 & 1.9 & 1.5 \\
\hline 31 & MF $4292^{*}$ & & 430 & 414.4 & -3.6 & 15.6 & 80.9 & 85.8 & 6.0 & 4.9 \\
\hline 32 & MF $4297^{*}$ & & 460 & 482.8 & 4.9 & 22.8 & 88.3 & 93.6 & 6.0 & 5.3 \\
\hline 33 & MF $4297^{*}$ & & 460 & 471.8 & 2.6 & 11.8 & 88.3 & 98.8 & 12.0 & 10.5 \\
\hline 34 & MF $4297^{*}$ & & 460 & 474.1 & 3.1 & 14.1 & 88.3 & 101.3 & 14.8 & 13.0 \\
\hline 35 & MF $7140^{*}$ & & 510 & 516.8 & 1.3 & 6.8 & 103.0 & 108.5 & 5.4 & 5.5 \\
\hline 36 & MF $7150^{*}$ & & 600 & 624.9 & 4.2 & 24.9 & 110.3 & 116.8 & 5.9 & 6.5 \\
\hline 37 & MF $7180^{*}$ & \multirow{6}{*}{$\mathrm{V}$} & 720 & 704.3 & -2.2 & 15.7 & 132.4 & 149.5 & 12.9 & 17.1 \\
\hline 38 & MF 7180 & & 720 & 710.8 & -1.3 & 9.2 & 132.4 & 131.0 & -1.0 & 1.4 \\
\hline 39 & VT BH180 & & 663 & 650.6 & -1.9 & 12.4 & 139.0 & 129.2 & -7.0 & 9.8 \\
\hline 40 & MF $7415^{*}$ & & 920 & 910.0 & -1.1 & 10.0 & 158.1 & 162.6 & 2.9 & 4.5 \\
\hline \multicolumn{2}{|c|}{ Average } & & 364.3 & 376.9 & & & 71.9 & 73.2 & & \\
\hline \multicolumn{2}{|c|}{ Standard error } & & 12.9 & 5.1 & & & 4.5 & 2.4 & & \\
\hline
\end{tabular}

* Tractors with maximum engine power values equal to or higher than those provided by manufacturers.

*** Official standard ISO TR 14396. 


\section{REFERENCES}

ASAE (AMERICAN SOCIETY OF AGRICULTURAL ENGINEER). SAE EP496.2: Agricultural Machinery Management. St Joseph, 2003. 6p.

ABNT (ASSOCIAÇÃO BRASILEIRA DE NORMAS TÉCNICAS). NBR ISO 3046/1: Motores de combustão interna - Desempenho - Parte 1: condições-padrão de referência e declarações de potência e de consumos de combustível e óleo lubrificante. Rio de Janeiro, 1995. 15p.

CORRÊA, I.M. et al. Performance of diesel engine fuelled with sunflower biodiesel blends. Ciência e Agrotecnologia, v. 32, n. 3, p. 923-928, May/Jun, 2008. Available from: <http://dx.doi. org/10.1590/S1413-70542008000300033>. Accessed: Sept. 07, 2015. doi: 10.1590/S1413-70542008000300033.

FIORESE, D.A. et al. Performance of na agricultural tractor engine in dynamometer with chicken oil biodiesel and binary mixtures with diesel oil. Ciência Rural, v. 42, n. 4, p. 660-666, Apr, 2012. Available from: <http://dx.doi.org/10.1590/S010384782012000400013>. Accessed: Mar. 12, 2015. doi: 10.1590/ S0103-84782012000400013.

GARAY, A.V.A. et al. Testing of agricultural tractors in México: power take off, hydraulic lift, security cabins and frames. Revista
Ciencias Técnicas Agropecuarias, v. 22, n. Esp., p. 6-14, Dec, 2013. Available from: <http://scielo.sld.cu/pdf/rcta/v22s1/ rcta01513.pdf $>$. Accessed: Feb. 10, 2015.

MÁRQUEZ, L. Tractores agrícolas: tecnología y utilización. Madrid: B\&H Grupo Editorial, 2012. 844p.

MIALHE, L.G. Máquinas agrícolas: ensaios e certificação. Piracicaba: FEALQ, 1996. 722p.

NIETIEDT, G.H. et al. Performance of a direct injection engine using soybeans methyl biodisel blends. Ciência Rural, v.41, p.1177-1182, Jul, 2011. Available from: <http://www.scielo. br/pdf/cr/v41n7/a2911cr4135.pdf $>$. Accessed: Mar. 11, 2015. doi:10.1590/S0103-84782011005000079.

SILVEIRA, G.M. et al. Classification of agricultural tractor according to their energy efficiency. Engenharia na Agricultura, v. 16, n. 2, p. 208-214, Apr/Jun, 2008. Available from: <http://www.seer.ufv.br/seer/index.php/reveng/article/ viewFile/18/8>.Accessed: Mar. 11, 2015. doi: 10.13083/14143984.v16n02a0.

OECD (ORGANIZATION FOR ECONOMIC COOPERATION AND DEVELOPMENT). CODE 2: standard code for the official testing of agricultural and forestry tractor performance. Paris, 2014. 104p 